\title{
Causal relationship between wages and prices in UK: VECM analysis and Granger causality testing
}

Dushko Josheski (dushkojosheski@gmail.com)

Risto Fotov (risto.fotov@ugd.edu.mk)

Darko Lazarov( darko.lazarov@ugd.edu.mk )

Cane Koteski (cane.koteski@ugd.edu.mk)

\section{Abstract}

In this paper the issue of causality between wages and prices in UK has been tested. OLS relationship between prices and wages is positive; productivity is not significant in determination of prices or wages too. These variables from these statistics we can see that are stationary at 1 lag, i.e. they are I(1) variables, except for CPI variables which is I(2) variable. From the VECM model, If the log wages increases by $1 \%$, it is expected that the log of prices would increase by 5.24 percent. In other words, a 1 percent increase in the wages would induce a 5.24 percent increase in the prices.About the short run parameters, the estimators of parameters associated with lagged differences of variables may be interpreted in the usual way.Productivity was exogenous repressor and it is deleted since it has coefficient no different than zero. The relation (causation) between these two variables is from CPI_log $\rightarrow$ real_wage_log .Granger causality test showed that only real wages influence CPI or consumer price index that proxies prices, this is one way relationship, price do not influence wages in our model.

Keywords: VECM, Granger causality, real wages, prices, cointegration, OLS 


\section{Introduction}

In the literature from this area there two sides of economist one that thinks that causality runs from wages to prices and the second that thinks that causality runs from wages to prizes. The evidence in the literature has evidence in support to both hypotheses. Granger causality test is easy to be applied in economics.OLS techniques have been applied to data, and to estimate the long run relationship we apply VECM analysis.

\section{Theoretical overview}

In this theoretical review some basic concepts in the theory of wages and prices are outlined, to explain in some extent: what are determinants of wages and prices from neo-classical and neo-keynesian perspective.

\section{The Issue of Time Consistency}

New Classical Analysis makes a distinction between anticipated and unanticipated changes in money supply.There exists superiority of fixed policy rules, low inflation requires monetary authorities to commit themselves to low-inflation policy. Government cannot credibly commit to low inflation policy if retain the right to conduct discretionary policy (Kydland,Prescott,1977). The model of optimal policy is as follows:

Let $\pi=\left(\pi_{1}, \pi_{2}, \ldots \ldots \pi_{\mathrm{T}}\right)$ be a sequence of policies for periods 1 to $\mathrm{T}$ and

$$
x=\left(x_{1}, x_{2} \ldots \ldots x_{\mathrm{T}}\right) \text { be the corresponding sequence of economic agents' decisions. }
$$

Assume an agreed social welfare function:

$\mathrm{S}\left(x_{1}, x_{2} \ldots \ldots x_{\mathrm{T}}, \pi_{1}, \pi_{2}, \ldots \ldots \pi_{\mathrm{T}}\right)$

And that agents' decisions in period t depend on all policy decisions and their own past decisions:

$$
x_{t}=X_{t}\left(x_{1}, x_{2} \ldots \ldots x_{t-1}, \pi_{1}, \pi_{2}, \ldots \ldots \pi_{\mathrm{T}}\right)
$$

An optimal policy is one which maximises (1) subject to (2). The issue of time consistency is: A policy $\pi$ is time consistent if for each $t, \pi_{t}$ maximises (1) taking as given previous economic agents' decisions and that future policy decisions are taken similarly.Optimal policies are time inconsistent

- therefore lack credibility

- discretionary policies lead to inferior outcomes 
- need credible pre-commitment

Consider a two period model in which $\pi_{2}$ is selected to maximise:

$\mathrm{S}\left(x_{1}, x_{2}, \pi_{1}, \pi_{2}\right)$

subject to:

$x_{1}=X_{1}\left(\pi_{1}, \pi_{2}\right) \quad$ and

$x_{2}=X_{2}\left(x_{1}, \pi_{1}, \pi_{2}\right)$

For the policy to be time consistent $\pi_{2}$ must maximise (3), given $x_{1}$ and $\pi_{1}$ and given constraint (4). Now we are going to eliminate inflatory bias:Low inflation rule not credible if government retains discretionary powers

- need to gain a reputation for maintaining a low inflation policy mix

- benefits from cheating < punishment costs

- or need to pre-commit to a low inflation policy goal

- central bank independence, 'golden rule' for fiscal policy

- but danger of democratic deficit?

\section{Sources of price rigidity}

New Keynesians suggest that small nominal price rigidities may have large macro effects

- incomplete indexing of prices in imperfectly competitive goods, labour and financial markets may be costly in terms of output instability

In goods market small 'menu costs' + unsynchronised price adjustments lead to staggered price adjustments

- fear that rapid price adjustments costly in decision-making time and cause excessive loss of existing customers

\section{Sources of wage rigidity}

\section{Efficiency wages}

Economy of high wages - productivity and non-wage labour costs may be endogenous in the wage-fixing process, even given excess supply of labour firms may not lower wages because their unit labour costs may rise $\rightarrow$ persistent unemployment. This repeals law of supply and demand, if the relationship between wages and productivity/non-wage costs varies across industry repeals law of one price. Version of efficiency wage model is:

A representative firm seeks to maximise its profits:

$$
\pi=\mathrm{Y}-w \mathrm{~L}
$$

where Y firm's output and $w \mathrm{~L}$ its wage costs and: 


$$
\mathrm{Y}=\mathrm{F}(e \mathrm{~L}) \quad \mathrm{F}^{\prime}>0, \mathrm{~F}^{\prime}{ }^{\prime}<0
$$

where e is workers' effort and:

$$
e=e(w) \quad \quad e^{\prime}>0
$$

there are $\mathrm{L}^{\mathrm{o}}$ identical workers who each supply 1 unit of labour inelastically

The problem of the firm is to:

$$
\max _{\mathrm{L} w} \mathrm{~F}(e(w) L-w L
$$

when there is unemployment the first order conditions for $\mathrm{L}$ and $w$ are:

$$
\begin{aligned}
& \mathrm{F}^{\prime}(e(w) L) e(w)-w=0 \\
& \mathrm{~F}^{\prime}(e(w) L) L e^{\prime}(w)-L=0
\end{aligned}
$$

rewriting (5) gives:

$$
\mathrm{F}^{\prime}(e(w) L)=w / e(w)
$$

substituting (7) into (5) gives:

$$
w e^{\prime}(w) / e(w)=1
$$

From (8) at the optimum, the elasticity of effort with respect to wage is 1 , i.e. the efficiency wage $\left(w^{*}\right)$ is that which satisfies (8) and minimises the cost of effective labour

With $\mathrm{N}$ firms each hiring $\mathrm{L}^{*}$ (the solution to (7), then total employment is $\mathrm{NL}^{*}$ and as long as $\mathrm{NL}^{*}<\mathrm{L}^{+}$we observe an efficiency wage $\left(w^{*}\right)$ and unemployment

\section{Literature overview}

Empirical facts on the price, wage and productivity relationship - The debate on the direction of causality between wages and prices is one of the central questions surrounding the literature on the determinants of inflation. The purpose of this review is to identify the key theories, concepts or ideas explaining the causality issue between prices and wages.We selected ten studies as to see what method they use in explanation of this relationship, most of the studies use panel methods but some use VECM model just like ours too. 
A summary of some studies on the price, wage and productivity relationship

\begin{tabular}{|c|c|c|}
\hline Studies & Title & Method \\
\hline Strauss, Wohar (2004) & $\begin{array}{l}\text { The Linkage Between Prices, Wages, } \\
\text { and Labor Productivity: } \\
\text { A Panel Study of Manufacturing Industries }\end{array}$ & $\begin{array}{l}\text { panel unit root and } \\
\text { panel cointegration } \\
\text { procedures }\end{array}$ \\
\hline $\begin{array}{c}\text { Saten Kumar, Don J. } \\
\text { Webber and Geoff Perry } \\
\text { (2008) }\end{array}$ & $\begin{array}{l}\text { Real wages, inflation and labour } \\
\text { productivity in Australia }\end{array}$ & $\begin{array}{c}\text { Cointegration; } \\
\text { Granger causality }\end{array}$ \\
\hline $\begin{array}{l}\text { Dubravko Mihaljek and } \\
\text { Sweta Saxena }\end{array}$ & $\begin{array}{l}\text { Wages, productivity and "structural" inflation } \\
\text { in emerging market economies }\end{array}$ & $\begin{array}{l}\text { Empirical methods } \\
\text {,correlations }\end{array}$ \\
\hline $\begin{array}{c}\text { Erica L. Groshen } \\
\text { Mark E. Schweitzer } \\
\text { (1997) }\end{array}$ & $\begin{array}{c}\text { The Effects of Inflation on Wage Adjustments in } \\
\text { Firm-Level Data: } \\
\text { Grease or Sand? }\end{array}$ & $\begin{array}{l}\text { 40-year } \\
\text { panel of wage changes }\end{array}$ \\
\hline $\begin{array}{l}\text { Kawasaki, Hoeller, Poret, } \\
1997\end{array}$ & $\begin{array}{c}\text { Modeling wages and prices for smaller OECD } \\
\text { countries }\end{array}$ & $\begin{array}{c}\text { Error correction } \\
\text { mechanism }\end{array}$ \\
\hline $\begin{array}{l}\text { Peter Flaschel, GÄoran } \\
\text { Kauermann, Willi Semmler } \\
\text { (2005) }\end{array}$ & $\begin{array}{c}\text { Testing Wage and Price Phillips Curves } \\
\text { for the United States }\end{array}$ & $\begin{array}{l}\text { parametric and non- } \\
\text { parametric estimation. }\end{array}$ \\
\hline SHIK HEO(2003) & $\begin{array}{c}\text { THE RELATIONSHIP BETWEEN EFFICIENCY } \\
\text { WAGES AND PRICE } \\
\text { INDEXATION IN A NOMINAL WAGE } \\
\text { CONTRACTING MODEL }\end{array}$ & $\begin{array}{l}\text { simple nominal wage } \\
\text { contracting model }\end{array}$ \\
\hline John B. Taylor(1998) & $\begin{array}{c}\text { STAGGERED PRICE AND WAGE SETTING } \\
\text { IN MACROECONOMICS }\end{array}$ & $\begin{array}{l}\text { time-dependent } \\
\text { pricing, staggered } \\
\text { price and wage setting }\end{array}$ \\
\hline $\begin{array}{l}\text { Gregory D. Hess and Mark } \\
\text { E. Schweitzer }\end{array}$ & $\begin{array}{l}\text { Does Wage Inflation } \\
\text { Cause Price Inflation? }\end{array}$ & $\begin{array}{l}\text { Granger Causality, } \\
\text { panel econometrics }\end{array}$ \\
\hline Raymond Robertson(2001) & $\begin{array}{c}\text { Relative Prices and Wage Inequality: } \\
\text { Evidence from Mexico }\end{array}$ & $\begin{array}{l}\text { Ordered Logit } \\
\text { Ordered Probit }\end{array}$ \\
\hline
\end{tabular}

This table shows that there exist theoretical and empirical models for prices and wages .This si a small sample of ten studies that study the relationship between wages, prices and productivity. 


\section{Data and the methodology}

We use time series data here for UK industry. Three variables are selected for the model. LRW is the log of real wage. This variable represents Real Hourly Compensation in Manufacturing, CPI Basis, in the United Kingdom. The data are from 1960 to 2009 although in our regressions we use data only from 1960 to 2007, because from 2008 financial crisis started which in terms of econometrics represents a huge structural break. This variable is indexed and as base is chosen 2002 $=100$. Second variable is LCPI which represents logarithm of consumer price index in UK for all items from 1960 to 2009, we use 1960-2007, and it is indexed 2005=100. LPROD is logarithm of productivity for UK manufacturing industry, this variable was calculated on a basis of average working hours in manufacturing industry and total output of manufactured goods, second variable was divided by first, and then logarithms were put. OLS and time series methods like VECM and co-integration are going to be applied for this series of data.

\section{OLS regressions}

I model: Price as a function of wages and productivity

$$
C P I=f(R W, P R O D U C T I V I T Y)
$$

II model: Wage is function of price and productivity.

$$
R W=f(C P I, P R O D U C T I V I T Y)
$$

This functional form is being applied on our data.

Ordinary least squares regressions are presented in the next page ${ }^{1}$ :

\footnotetext{
${ }^{1}$ For detailed output see Appendix 1 OLS regressions
} 


\begin{tabular}{|c|c|c|c|c|c|}
\hline Variables & $C P I=f(R V$ & DUCTIVITY & & $R W=f(C$ & DUCTIVITY) \\
\hline \multirow{6}{*}{$\log$} & (1) & (2) & (3) & (4) & (5) \\
\hline & LRW & $0.42^{* *}$ & \multirow{5}{*}{$\log$} & LCPI & $0.21^{* *}$ \\
\hline & LPROD & -0.017 & & LPROD & 0.06 \\
\hline & CONST & $5.81^{* * * *}$ & & CONST & $3.33^{* * * *}$ \\
\hline & $\mathrm{AC}$ test & $0.001^{* * * *}$ & & $\mathrm{AC}$ test & $0.794^{\text {**** }}$ \\
\hline & Ramsey test & $0.019^{*}$ & & Ramsey test & $0.178^{\text {**** }}$ \\
\hline \multirow{5}{*}{$\Delta \log$} & $\Delta \mathrm{LRW}$ & 0.15 & \multirow{5}{*}{$\Delta \log$} & $\Delta \mathrm{LCPI}$ & 0.17 \\
\hline & $\triangle \mathrm{LPROD}$ & -0.0051 & & $\triangle \mathrm{LPROD}$ & 0.038 \\
\hline & CONST & 0.053 & & CONST & 0.017 \\
\hline & $\mathrm{AC}$ test & 0.000 & & $\mathrm{AC}$ test & 0.000 \\
\hline & Ramsey test & $0.943^{* * *}$ & & Ramsey test & $0.943^{* * *}$ \\
\hline
\end{tabular}

Note 1: *** - significant at $1 \%$ level of significance; ** - significant at $5 \%$ level of significance; * - significant at $10 \%$ level of significance. The AC tests indicate the p-value of the Breusch-Godfrey LM test for autocorrelation with $\mathrm{H}_{0}$ : no serial correlation and $\mathrm{H}_{\mathrm{a}}$ : $\mathrm{H}_{0}$ is not true

Here OLS relationship between prices and wages is positive, also and between productivity and prices and productivity and wages except for the fact that these relationships are not significant. These models in column 1 can be represented in a form:

lcpi $=\beta_{1}$ lrw $+\beta_{2}$ lprod $+\beta_{0}$, where $\beta_{0}$ is intercept, $\beta_{1}$ and $\beta_{2}$ are elasticities that measure elasticity of wages to prices and productivity to prices respectively. Second model in this column is: $\Delta l c p i=\beta_{1} \Delta l r w+\beta_{2} \Delta l p r o d+\beta_{0}$, this is the case of first differences of the variables.

Autocorrelation in the models from column I is a serious problem, OLS time series do suffer from serial correlation. Functional form significant at all conventional levels of significance. Finally the estimated coefficients on wages to prices (and vice versa) are positive. This notion is not confirmed with Granger causality test, except for the case that Log of real wages causes LCPI at $5 \%$ level of significance. ${ }^{2}$

\footnotetext{
${ }^{2}$ See Appendix 2 Granger causality test
} 


\begin{tabular}{|c|c|c|}
\hline & Log-levels & First-differences \\
\hline $\begin{array}{l}\text { NON-CAUSAL } \\
\text { VARIABLES }\end{array}$ & LR stat & LR stata \\
\hline LCPI & 0.316 & 0.801 \\
\hline LRW & $0.049^{* *}$ & 0.133 \\
\hline
\end{tabular}

Note 1: *** - significant at $1 \%$ level of significance; ** - significant at $5 \%$ level of significance; * - significant at $10 \%$ level of significance.

\section{Impulse response graph}

On the next graph is given impulse Response for a shock of variables, prices and wages.

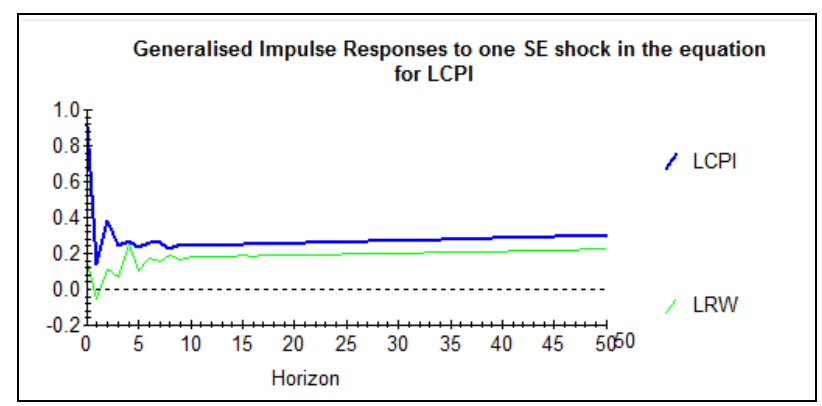

\section{Unit root tests ${ }^{3}$}

Unit root tests statistics are given in a Table below

\begin{tabular}{|l|c|c|}
\hline $\begin{array}{l}\text { Variables tested for } \\
\text { unit roots }\end{array}$ & Test statistic & Decision \\
\hline real_wage_log & -1.4627 & Series is non-stationary \\
\hline real_wage_log_d1 & $-3.5693^{* *}$ & Series is stationary \\
\hline CPI_log & -1.1164 & Series is non-stationary \\
\hline CPI_log_d1 & -2.3459 & Series is non-stationary \\
\hline CPI_log_d1_d1_d1 & $-7.0234^{* * *}$ & Series is stationary \\
\hline
\end{tabular}

$\begin{array}{llll}\text { Critical values for the test at } & 1 \% & 5 \% & 10 \% \\ & -3.96 & -3.41 & -3.13\end{array}$

Note 1: $* * *$ - significant at $1 \%$ level of significance; $* *$ - significant at $5 \%$ level of significance; $*$ - significant at $10 \%$ level of significance.

\footnotetext{
${ }^{3}$ See Appendix 3 Unit root tests
} 
These variables from these statistics we can see that are stationary at 1 lag, i.e. they are I(1) variables, except for CPI variables which is I(2) variable. These variables are graphically presented as non-stationary and their differences as stationary in the unit root section Appendix 3.

\section{Johansen Trace test (co-integration test) ${ }^{4}$}

Whereas the Akaike Information Criterion (AIC) tends to overestimate the optimal lag order, the Hannan-Quinn information criterion (HQ) provides the most consistent estimates, thus it will be considered as the most reliable criterion.

\section{Cointegration rank}

On the next table is summarized the decision fro with how many lags to continue testing.

\begin{tabular}{|c|c|c|c|c|}
\hline Variables & Deterministic & \multicolumn{3}{|c|}{ Johansen trace test } \\
\hline \multirow[t]{2}{*}{ CPI_log } & \multirow[b]{2}{*}{ Constant } & Lag order & LR-stat & p-value \\
\hline & & 1 & 2.65 & 0.6540 \\
\hline $\begin{array}{l}\text { and } \\
\text { Real_wage_log }\end{array}$ & $\begin{array}{c}\text { Constant and a } \\
\text { trend }\end{array}$ & 1 & 4.97 & 0.6072 \\
\hline
\end{tabular}

We reject the null for zero lags and we cannot reject the $r=1$, so we will accept 1 cointegrating vector.

\section{Estimated cointegrating vector}

Next we are going to present the estimation for cointegrating vector. This estimation does not include intercepts and does not include trends.

\footnotetext{
${ }^{4}$ See Appendix 4 test for cointegration
} 
Chosen order $=1$

44 observations from 1964 to 2007

Vector 1

LRW $\quad .24600$

$(-1.0000)$

LCPI $\quad-.18411$

$(.74839)$

List of variables included in the cointegrating vector:

LRW LCPI

These vectors are normalized in brackets.

\section{Estimated long run coefficient using ARDL approach}

Long run coefficient between logarithm of real wages and logarithm of prizes is positive and statistically significant.

Estimated Long Run Coefficients using the ARDL Approach

ARDL $(1,0)$ selected based on Schwarz Bayesian Criterion

Dependent variable is LRW

44 observations used for estimation from 1964 to 2007

Regressor Coefficient Standard Error T-Ratio[Prob]

$\begin{array}{llll}\text { LCPI } & .74158 & .030294 & 24.4796[.000]\end{array}$

\section{VECM model}

VECM model is presented in the matrix form below

Coefficient matrix

$\left[\begin{array}{c}d\left(C P I_{-} \log \right)(t) \\ d(\text { real_wage_log })(t)\end{array}\right]=\left[\begin{array}{l}-0.105 \\ -0.031\end{array}\right]\left[\left[\begin{array}{ll}1.000 & -5.246\end{array}\right]\left[\begin{array}{c}C P I(\log (t-1) \\ \text { real_wage } \log (t-1)\end{array}\right]+[15.325][\right.$ CONST $\left.]\right]$ $+\left[\begin{array}{l}-0.010 \\ -0.003\end{array}\right][\operatorname{TREND}(t)]+\left[\begin{array}{c}u 1(t) \\ u 2(t)\end{array}\right]$

VECM output consists of coefficients. Estimation - The VECM model was estimated using the Two Stage procedure ( $S 2 S)$, with Johansen procedure being used in the first stage and Feasible Generalized Least Squares (FGLS) procedure being used in the second stage. The 
Loading coefficients-even though they may be considered as arbitrary to some extent due to the fact that they are determined by normalization of co-integrating vectors, their $t$ ratios may be interpreted in the usual way as being conditional on the estimated co-integration coefficients, (Lütkhepohl and Krätzig, 2004; Lütkhepohl and Krätzig, 2005,).In our case loading coefficients have t-ratios [-12.616] [-3.907] respectively. Thus, based on the presented evidence, it can be argued that co-integration relation resulting from normalization of cointegrating vector enters significantly.Table of t-stat matrix is given below.

t-stat matrix

$$
\begin{aligned}
& {\left[\begin{array}{c}
d\left(C P I_{-} \log \right)(t) \\
d(\text { real_wage_log })(t)
\end{array}\right]=\left[\begin{array}{c}
-12.616 \\
-3.907
\end{array}\right]\left[\left[\begin{array}{ll}
\ldots & -10.401
\end{array}\right]\left[\begin{array}{c}
C P I(\log (t-1) \\
\text { real_wage } \log (t-1)
\end{array}\right]+[8.779][\text { CONST }]\right.} \\
& +\left[\begin{array}{c}
-10.933 \\
-3.068
\end{array}\right][\operatorname{TREND}(t)]+\left[\begin{array}{l}
u 1(t) \\
u 2(t)
\end{array}\right]
\end{aligned}
$$

Co-integration vectors -The model we can arrange as follows

$$
e c^{f g l s}=C P I \_l o g-5.246 r e a l_{-} \text {wage } \_ \text {log }
$$

If we rearrange

$$
C P I \_\log =5.246 r e a l_{-} \text {wage } \_\log +e c^{f g l s}
$$

If the $\log$ wages increases by $1 \%$, it is expected that the $\log$ of prices would increase by 5.24 percent. In other words, a 1 percent increase in the log wages would induce a 5.24 percent increase in the log of prices.

Short-run parameters - The estimators of parameters associated with lagged differences of variables may be interpreted in the usual way.Productivity was exogenous regressor and it is deleted since it has coefficient no different than zero. 
Deterministic Terms -Trend term has statistically significant though very small impact in the two equations.

\section{Conclusion}

In our paper we made several conclusions about the relationship between prices and wages. First there exist positive and significant relationship between the two variables and causation is from real wages to CPI. As our Vector Error correction model (VECM) showed on average $1 \%$ increase in $\log$ of real wages induces by $5.3 \%$ increase in CPI for all items in UK, i.e. this means that increase in wages causes inflation in UK, this notion was confirmed with the Granger causality test. The relation (causation) between these two variables is from CPI_log $\rightarrow$ real_wage_log. 


\section{Appendix 1 OLS regressions}

\begin{tabular}{|c|c|c|c|}
\hline \multicolumn{4}{|c|}{ Dependent variable is LRW } \\
\hline \multicolumn{4}{|c|}{ 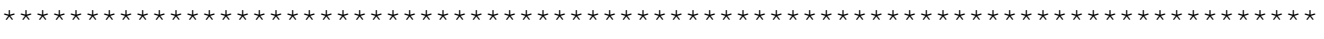 } \\
\hline Regressor Coet & ficient & Standard Error $\quad \mathrm{T}$ & -Ratio [Prob] \\
\hline $\mathrm{C}$ & 3.3245 & 1.0646 & $3.1228[.003]$ \\
\hline LCPI & .20940 & .10131 & $2.0670[.045]$ \\
\hline LPROD & 055376 & .036035 & $1.5367[.131]$ \\
\hline \multicolumn{4}{|c|}{ 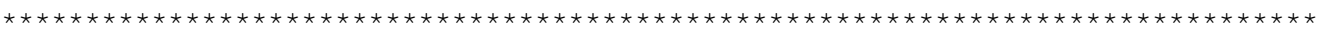 } \\
\hline R-Squared & .13049 & R-Bar-Squared & .091842 \\
\hline S.E. of Regression & .87654 & F-stat. $\quad F(2,45)$ & $3.3766[.043]$ \\
\hline Mean of Dependent Variable & 6.0656 & S.D. of Dependent Variable & .91980 \\
\hline Residual Sum of Squares & 34.5748 & Equation Log-likelihood & -60.2352 \\
\hline $\begin{array}{l}\text { Akaike Info. Criterion } \\
\text { DW-statistic }\end{array}$ & $\begin{array}{r}-63.2352 \\
2.0656\end{array}$ & Schwarz Bayesian Criterion & -66.0420 \\
\hline
\end{tabular}

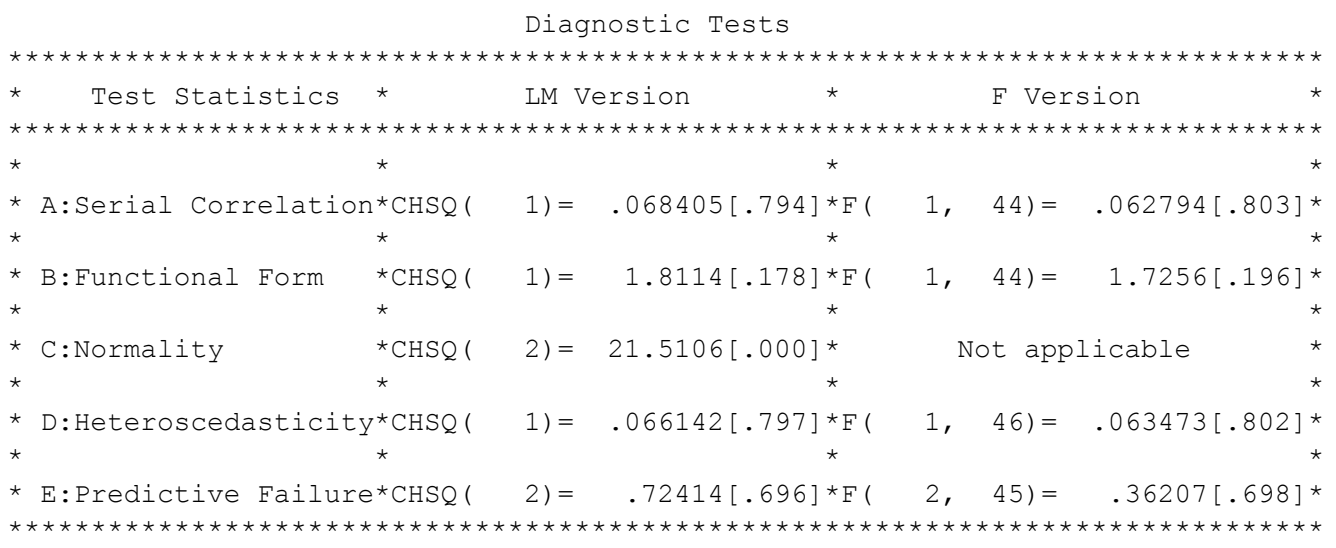

A:Lagrange multiplier test of residual serial correlation

B:Ramsey's RESET test using the square of the fitted values

$C$ :Based on a test of skewness and kurtosis of residuals

$\mathrm{D}$ :Based on the regression of squared residuals on squared fitted values

$\mathrm{E}: \mathrm{A}$ test of adequacy of predictions (Chow's second test)

Test for autocorrelation

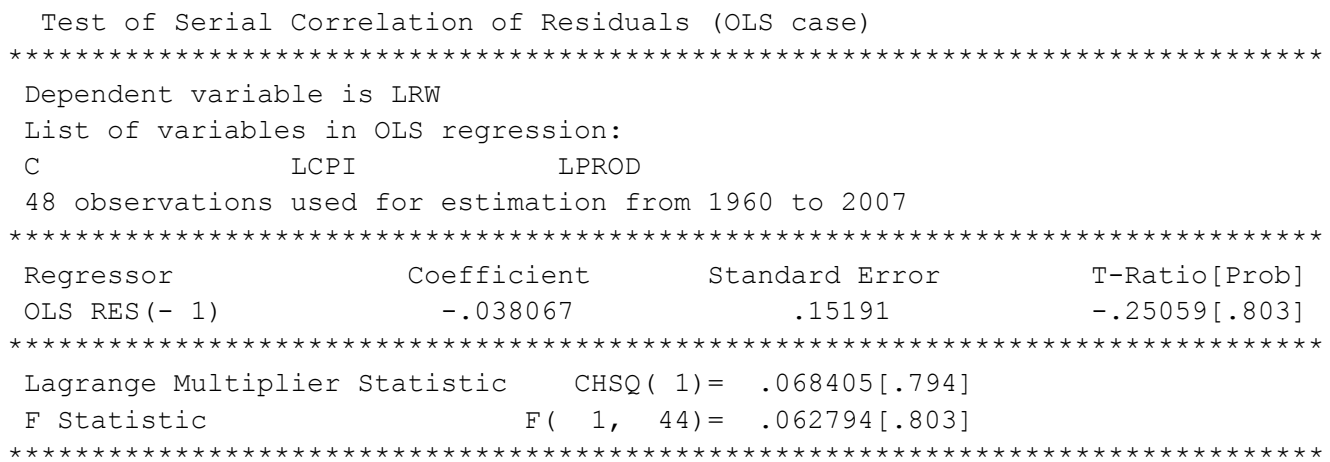


Ordinary Least Squares Estimation

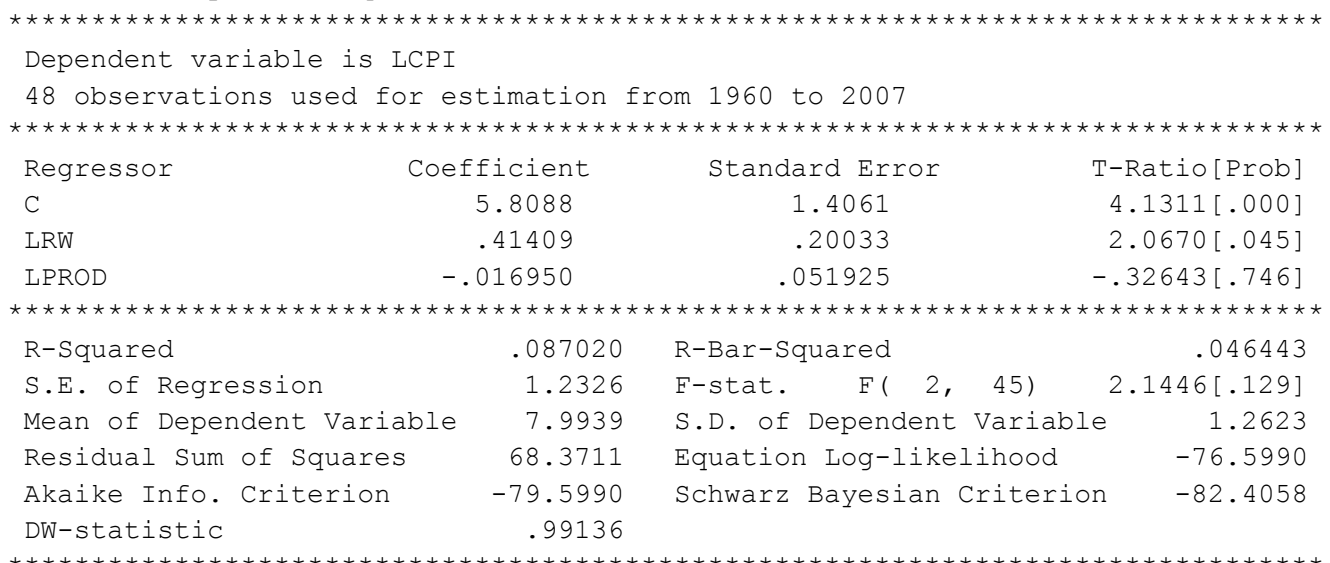

Diagnostic Tests

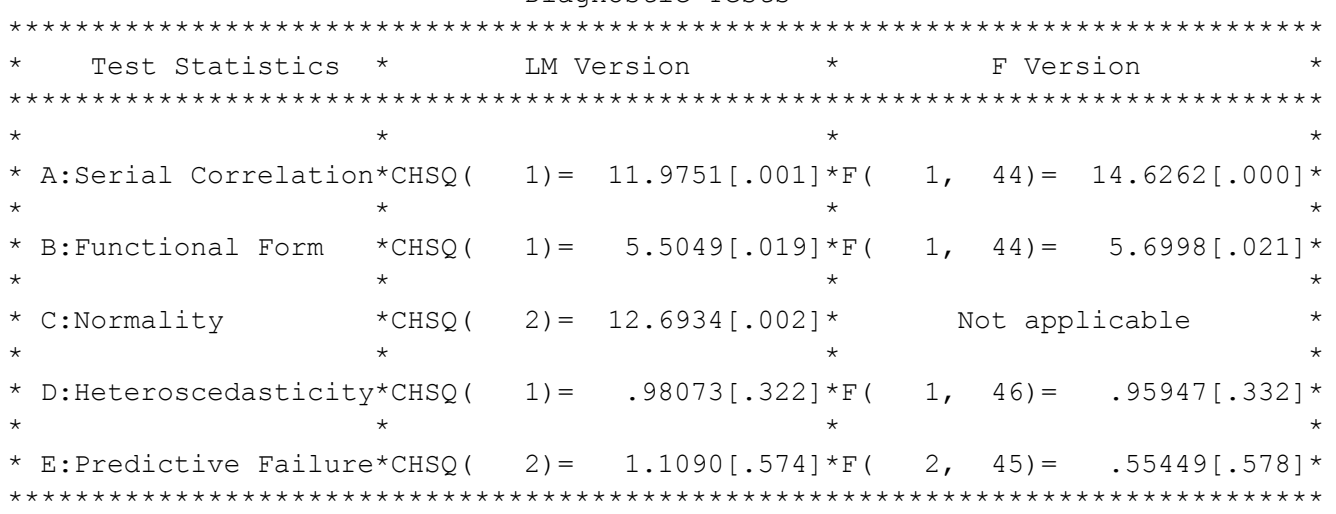

A:Lagrange multiplier test of residual serial correlation

B:Ramsey's RESET test using the square of the fitted values

$\mathrm{C}$ :Based on a test of skewness and kurtosis of residuals

$D$ :Based on the regression of squared residuals on squared fitted values

$\mathrm{E}: \mathrm{A}$ test of adequacy of predictions (Chow's second test)

Test for autocorrelation

Test of Serial Correlation of Residuals (OLS case)

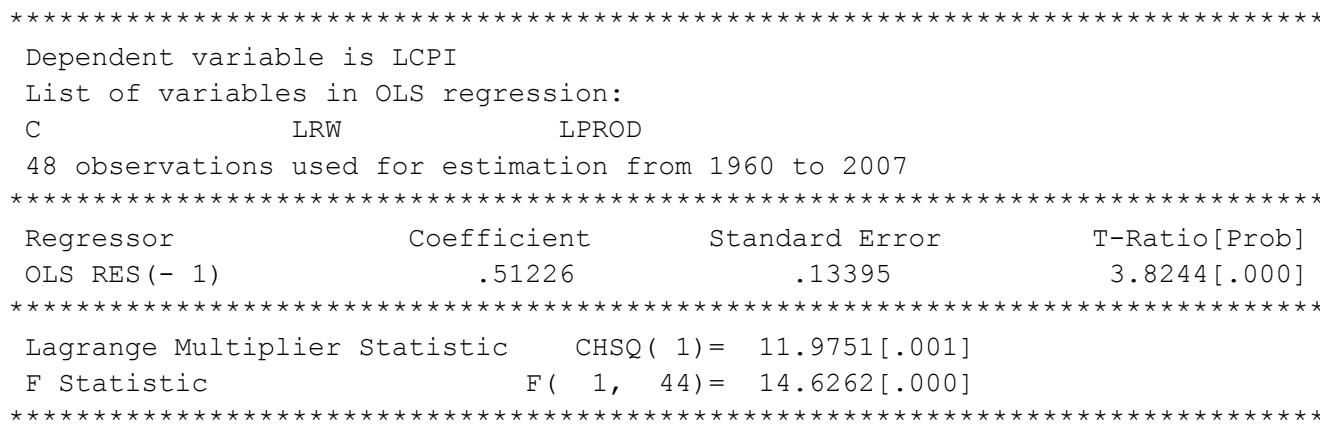


Ordinary Least Squares Estimation

\begin{tabular}{|c|c|c|c|}
\hline \multicolumn{4}{|c|}{ Dependent variable is DLRW } \\
\hline \multicolumn{4}{|c|}{ 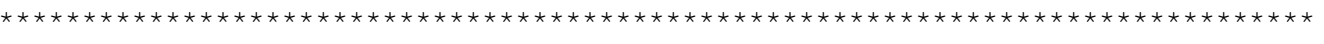 } \\
\hline Regressor Coef & ficient & Standard Error & T-Ratio[Prob] \\
\hline $\mathrm{C}$ & 016183 & .18532 & $.087324[.931]$ \\
\hline DLCPI & .16411 & .15873 & $1.0340[.307]$ \\
\hline DLPROD & 037112 & .035729 & $1.0387[.305]$ \\
\hline \multicolumn{4}{|c|}{ 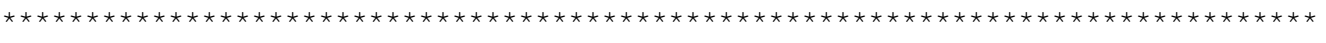 } \\
\hline R-Squared & .046583 & R-Bar-Squared & .0032454 \\
\hline S.E. of Regression & 1.2690 & F-stat. $\quad F(2, \quad 44)$ & $1.0749[.350]$ \\
\hline Mean of Dependent Variable & .026783 & S.D. of Dependent Variable & e $\quad 1.2711$ \\
\hline Residual Sum of Squares & 70.8578 & Equation Log-likelihood & -76.3375 \\
\hline Akaike Info. Criterion & -79.3375 & Schwarz Bayesian Criterion & -82.1127 \\
\hline DW-statistic & 2.9188 & & \\
\hline
\end{tabular}

Diagnostic Tests

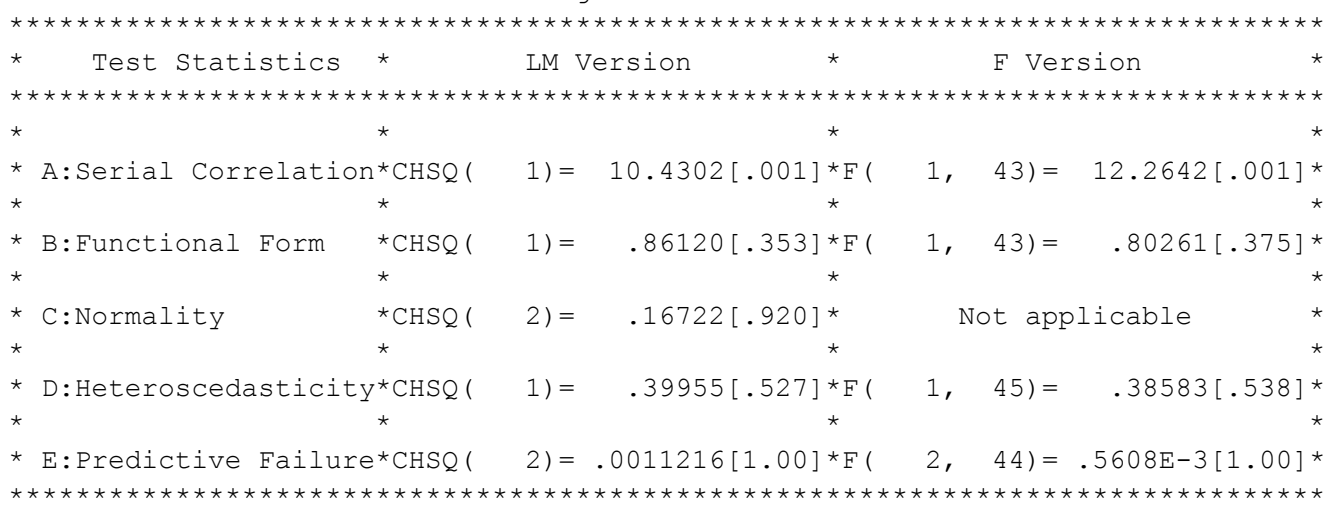

A:Lagrange multiplier test of residual serial correlation

B:Ramsey's RESET test using the square of the fitted values

$C$ :Based on a test of skewness and kurtosis of residuals

$\mathrm{D}$ :Based on the regression of squared residuals on squared fitted values

$\mathrm{E}: \mathrm{A}$ test of adequacy of predictions (Chow's second test)

Test for autocorrelation

Test of Serial Correlation of Residuals (OLS case)

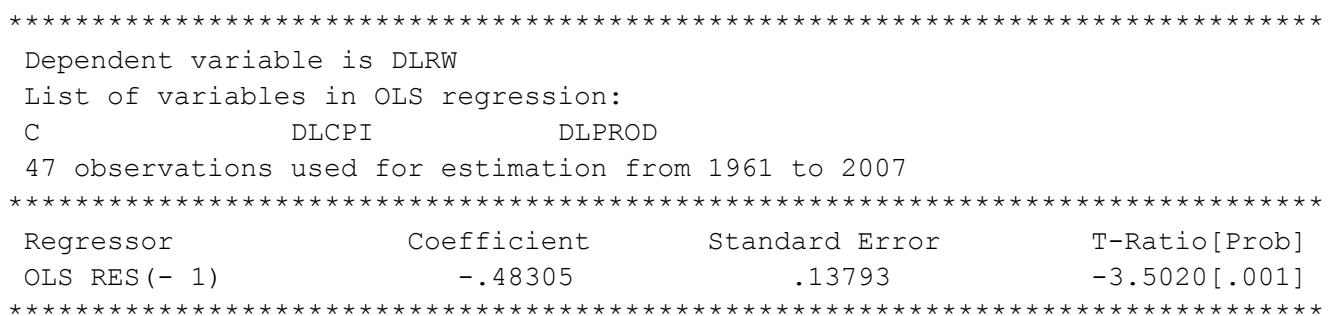

Lagrange Multiplier Statistic CHSQ( 1)= 10.4302[.001]

F Statistic $\quad F(1,43)=12.2642[.001]$

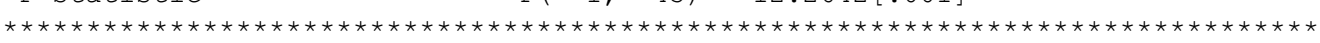


Ordinary Least Squares Estimation

\begin{tabular}{|c|c|c|c|}
\hline \multicolumn{4}{|c|}{ Dependent variable is DLCPI } \\
\hline \multicolumn{4}{|c|}{ 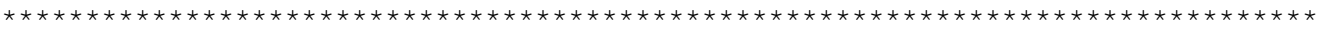 } \\
\hline Regressor & ficient & Standard Error & T-Ratio [Prob] \\
\hline $\mathrm{C}$ & 052526 & .17375 & $.30230[.764]$ \\
\hline DLRW & .14454 & .13979 & $1.0340[.307]$ \\
\hline DLPROD & 051790 & .033930 & $-.15264[.879]$ \\
\hline \multicolumn{4}{|c|}{ 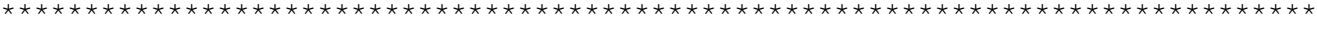 } \\
\hline R-Squared & .023721 & R-Bar-Squared & -.020655 \\
\hline S.E. of Regression & 1.1909 & F-stat. $\quad F(2, \quad 44)$ & $.53455[.590]$ \\
\hline Mean of Dependent Variable & .056205 & S.D. of Dependent Variable & e $\quad 1.1788$ \\
\hline \multirow{2}{*}{$\begin{array}{l}\text { Residual Sum of Squares } \\
\text { Akaike Info. Criterion }\end{array}$} & 62.4047 & Equation Log-likelihood & -73.3522 \\
\hline & -76.3522 & Schwarz Bayesian Criterion & -79.1274 \\
\hline \multicolumn{4}{|c|}{ DW-statistic $\quad 3.0912$} \\
\hline
\end{tabular}

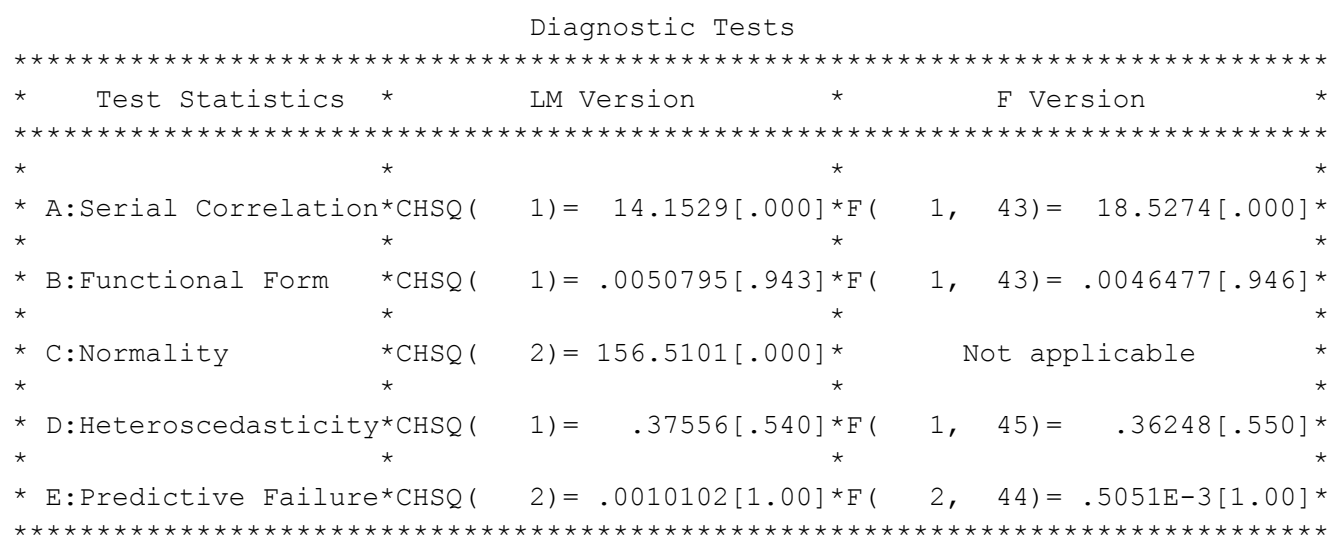

A:Lagrange multiplier test of residual serial correlation

B:Ramsey's RESET test using the square of the fitted values

$C$ :Based on a test of skewness and kurtosis of residuals

$D$ :Based on the regression of squared residuals on squared fitted values

$\mathrm{E}: \mathrm{A}$ test of adequacy of predictions (Chow's second test)

Test of Serial Correlation of Residuals (OLS case)

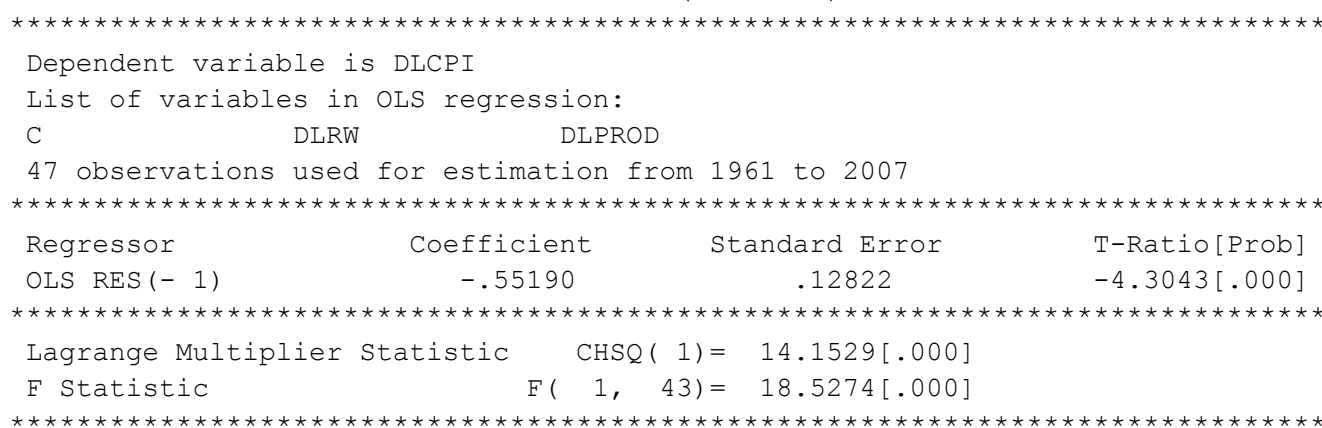


Appendix 2 Granger causality test

Granger causality

LR Test of Block Granger Non-Causality in the VAR

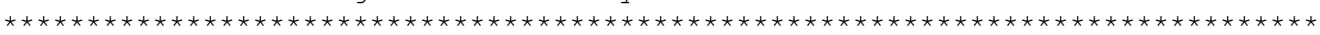

Based on 46 observations from 1964 to 2009. Order of VAR $=4$

List of variables included in the unrestricted VAR:

LCPI LRW

Maximized value of log-likelihood $=-117.7206$

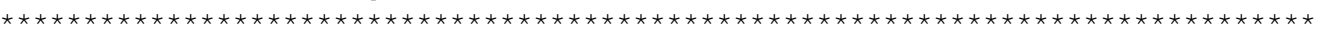

List of variable(s) assumed to be "non-causal" under the null hypothesis:

LCPI

Maximized value of log-likelihood $=-120.0863$

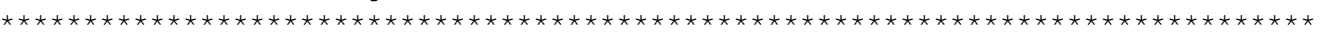

LR test of block non-causality, CHSQ( 4)=4.7314[.316]

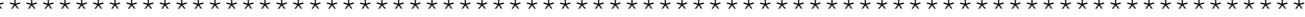

The above statistic is for testing the null hypothesis that the coefficients

of the lagged values of:

LCPI

in the block of equations explaining the variable(s):

LRW

are zero. The maximum order of the $\operatorname{lag}(\mathrm{s})$ is 4 .

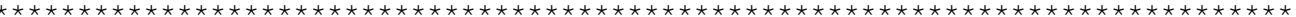

LR Test of Block Granger Non-Causality in the VAR

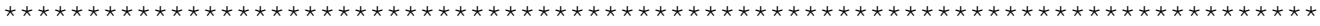

Based on 46 observations from 1964 to 2009. Order of VAR $=4$

List of variables included in the unrestricted VAR:

LCPI LRW

Maximized value of log-likelihood $=-117.7206$

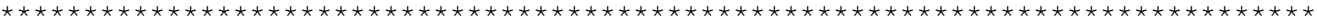

List of variable(s) assumed to be "non-causal" under the null hypothesis:

LRW

Maximized value of log-likelihood $=-122.4993$

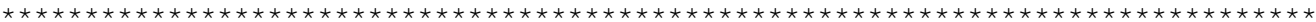

LR test of block non-causality, CHSQ( 4)=9.5574[.049]

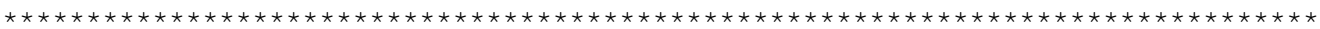

The above statistic is for testing the null hypothesis that the coefficients

of the lagged values of:

LRW

in the block of equations explaining the variable(s):

LCPI

are zero. The maximum order of the $\operatorname{lag}(\mathrm{s})$ is 4.

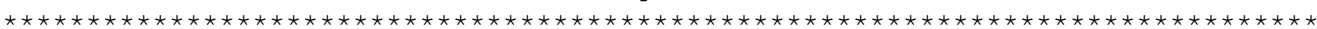


LR Test of Block Granger Non-Causality in the VAR

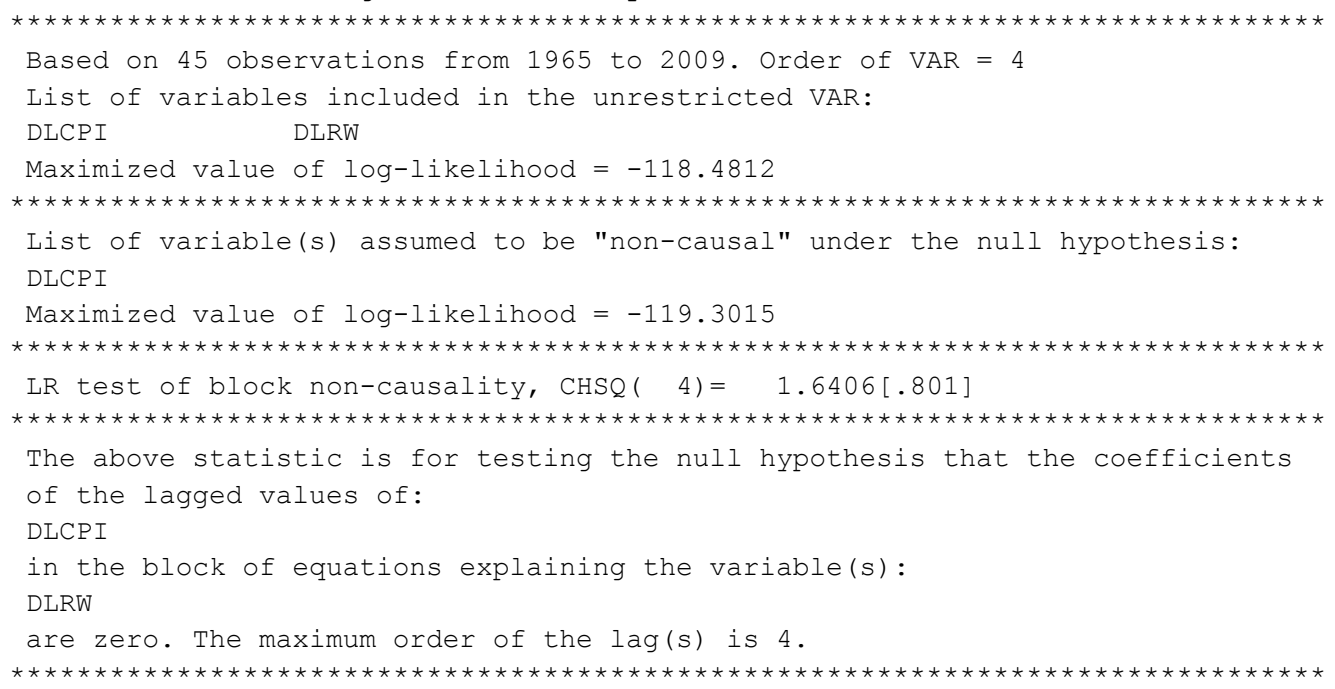

LR Test of Block Granger Non-Causality in the VAR

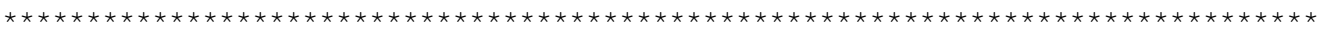

Based on 45 observations from 1965 to 2009. Order of VAR $=4$

List of variables included in the unrestricted VAR:

DLCPI DLRW

Maximized value of log-likelihood $=-118.4812$

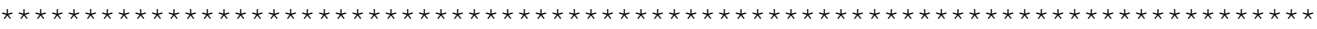

List of variable(s) assumed to be "non-causal" under the null hypothesis:

DLRW

Maximized value of log-likelihood $=-122.0135$

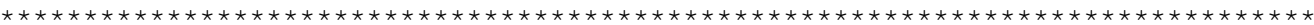

LR test of block non-causality, CHSQ( 4) $=7.0647[.133]$

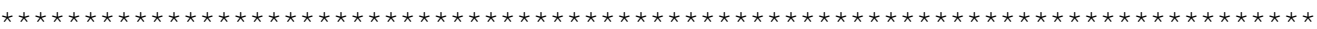

The above statistic is for testing the null hypothesis that the coefficients

of the lagged values of:

DLRW

in the block of equations explaining the variable(s):

DLCPI

are zero. The maximum order of the lag(s) is 4.

LR Test of Block Granger Non-Causality in the VAR

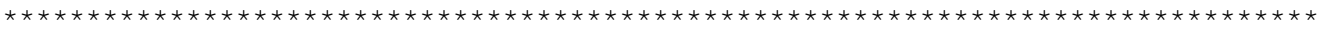

Based on 45 observations from 1965 to 2009. Order of VAR $=4$

List of variables included in the unrestricted VAR:

DLRW DLPROD

Maximized value of log-likelihood $=-185.0739$

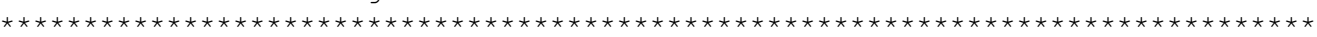

List of variable(s) assumed to be "non-causal" under the null hypothesis: DLPROD

Maximized value of log-likelihood $=-187.5924$

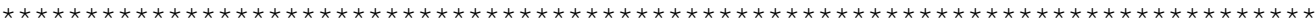

LR test of block non-causality, CHSQ( 4)= 5.0369[.284]

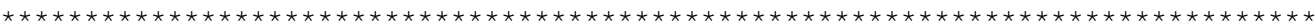

The above statistic is for testing the null hypothesis that the coefficients

of the lagged values of:

DLPROD

in the block of equations explaining the variable(s):

DLRW

are zero. The maximum order of the $\operatorname{lag}(\mathrm{s})$ is 4 .

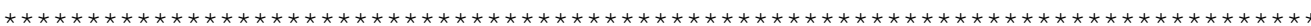


LR Test of Block Granger Non-Causality in the VAR

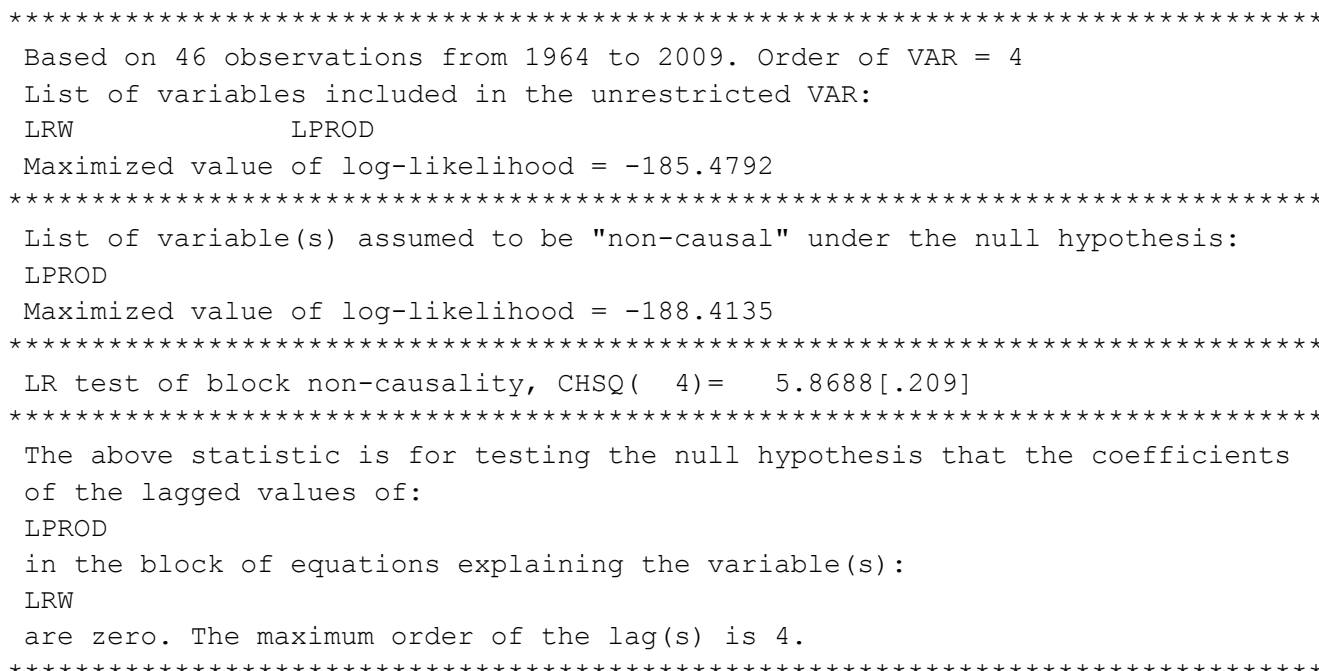

\section{Appendix 3 Unit root tests}

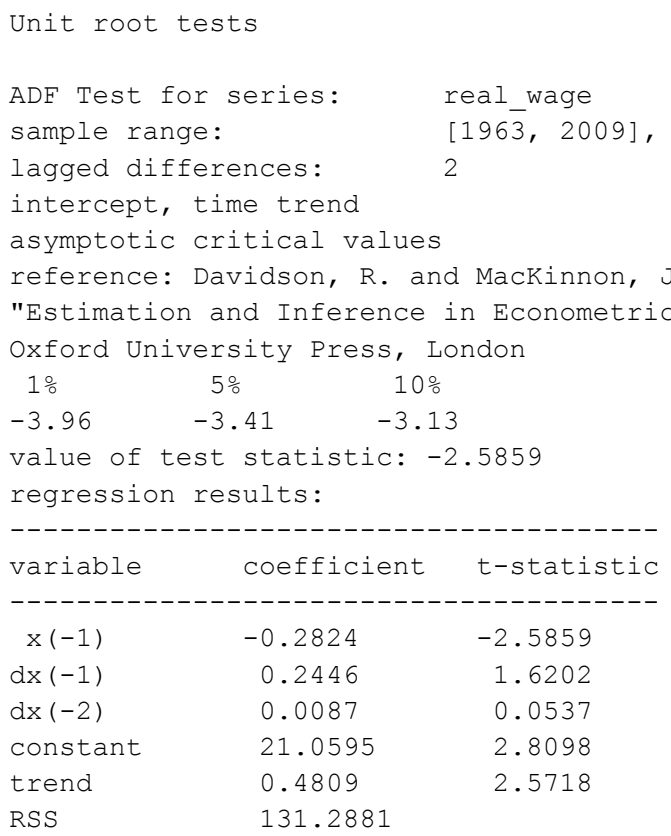

OPTIMAL ENDOGENOUS LAGS FROM INFORMATION CRITERIA

sample range:

$[1971,2009], T=39$

optimal number of lags (searched up to 10 lags of 1 . differences):

Akaike Info Criterion: 1

Final Prediction Error: 1

Hannan-Quinn Criterion: 0

Schwarz Criterion: 0 


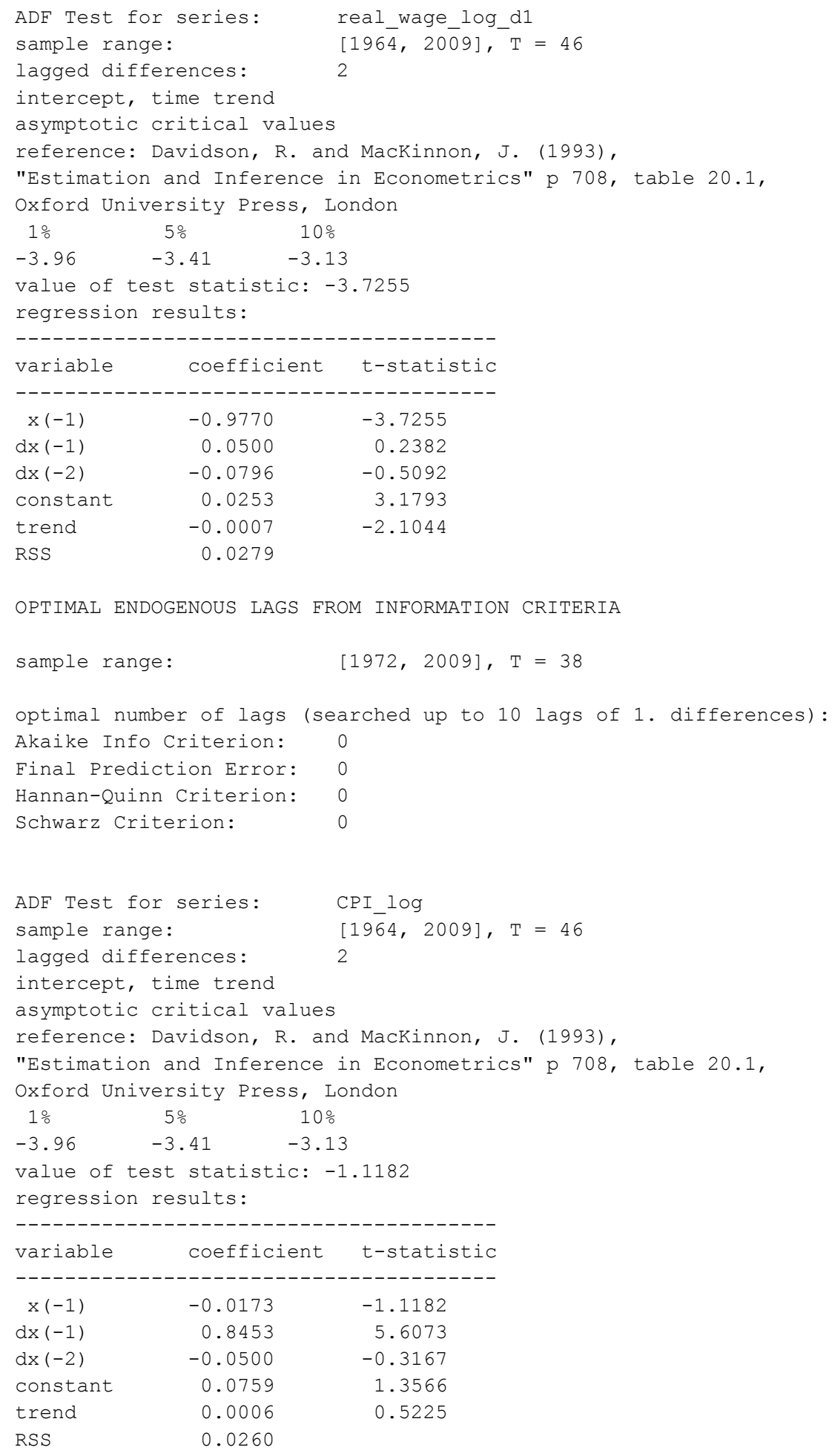

OPTIMAL ENDOGENOUS LAGS FROM INFORMATION CRITERIA

$\begin{array}{lcc}\text { variable } & \text { coefficient } & \text { t-statistic } \\ - & -0.0173 & -1.1182 \\ x(-1) & 0.8453 & 5.6073 \\ d x(-1) & -0.0500 & -0.3167 \\ d x(-2) & 0.0759 & 1.3566 \\ \text { constant } & 0.0006 & 0.5225 \\ \text { trend } & 0.0260 & \\ \text { RSS } & & \end{array}$

OPTIMAL ENDOGENOUS LAGS FROM INFORMATION CRITERIA

sample range:

$[1972,2009], T=38$

optimal number of lags (searched up to 10 lags of 1 . differences): Akaike Info Criterion: 6

Final Prediction Error: 1

Hannan-Quinn Criterion: 1

Schwarz Criterion: 


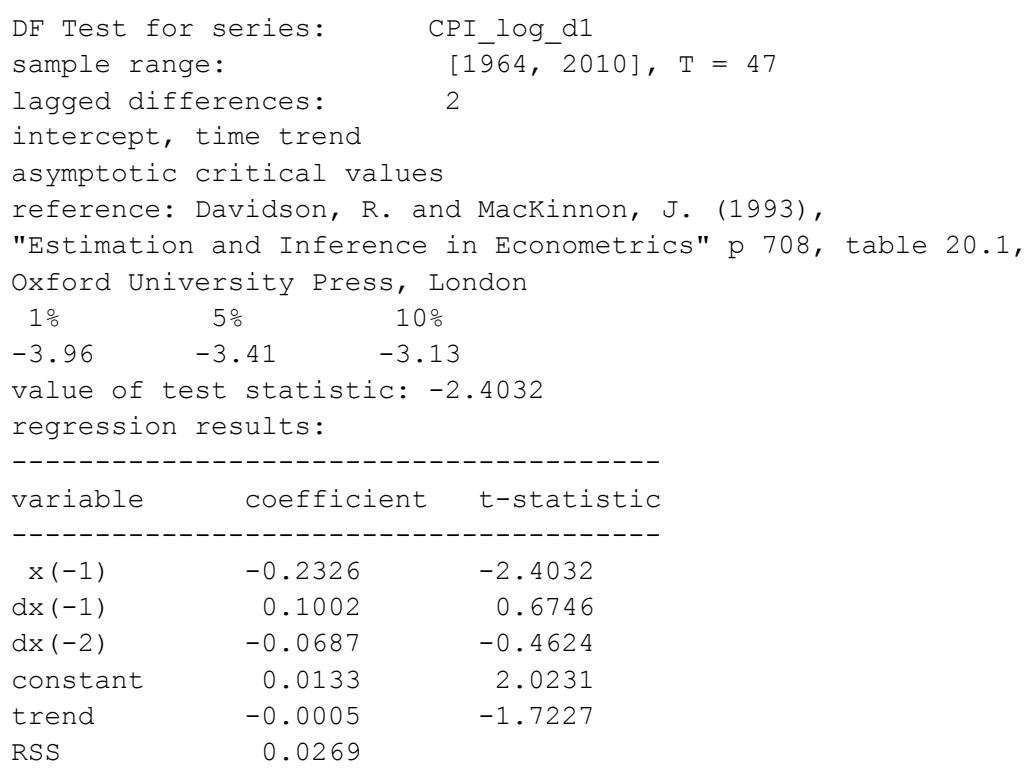

$\begin{array}{lrr}\text { variable } & \text { coefficient } & \text { t-statistic } \\ - & -0.2326 & -2.4032 \\ x(-1) & 0.1002 & 0.6746 \\ d x(-1) & -0.0687 & -0.4624 \\ d x(-2) & 0.0133 & 2.0231 \\ \text { constant } & -0.0005 & -1.7227 \\ \text { trend } & 0.0269 & \\ \text { RSS } & \end{array}$

OPTIMAL ENDOGENOUS LAGS FROM INFORMATION CRITERIA

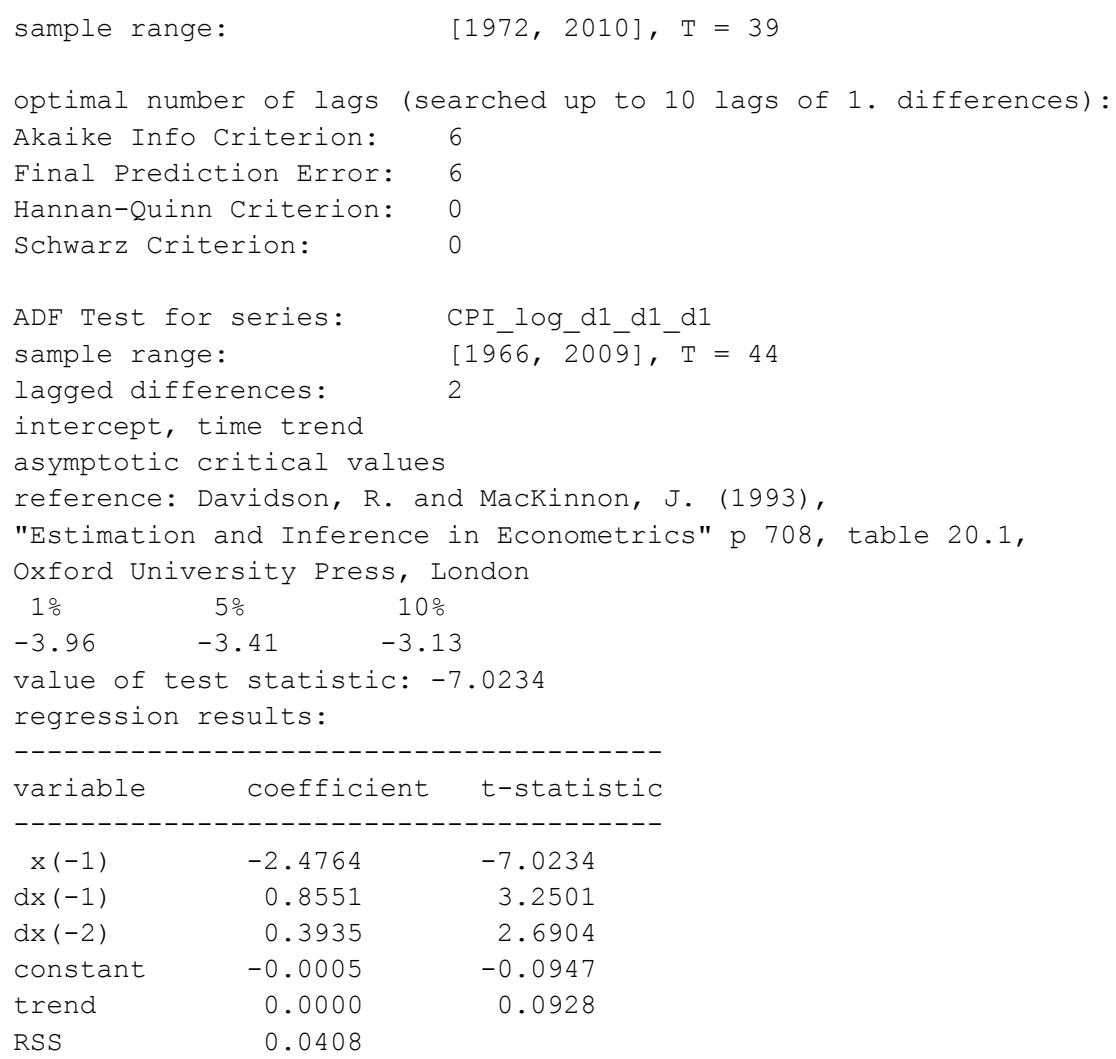

$\begin{array}{lcc} & & \\ \text { variable } & \text { coefficient } & \text { t-statistic } \\ - & -2.4764 & -7.0234 \\ x(-1) & 0.8551 & 3.2501 \\ d x(-1) & 0.3935 & 2.6904 \\ d x(-2) & -0.0005 & -0.0947 \\ \text { constant } & 0.0000 & 0.0928 \\ \text { trend } & 0.0408 & \\ \text { RSS } & & \end{array}$

OPTIMAL ENDOGENOUS LAGS FROM INFORMATION CRITERIA

sample range:

$[1974,2009], T=36$

optimal number of lags (searched up to 10 lags of 1 . differences): Akaike Info Criterion: 3 Final Prediction Error: 3 Hannan-Quinn Criterion: 3 Schwarz Criterion: 3 
Graphic presentation of the variables
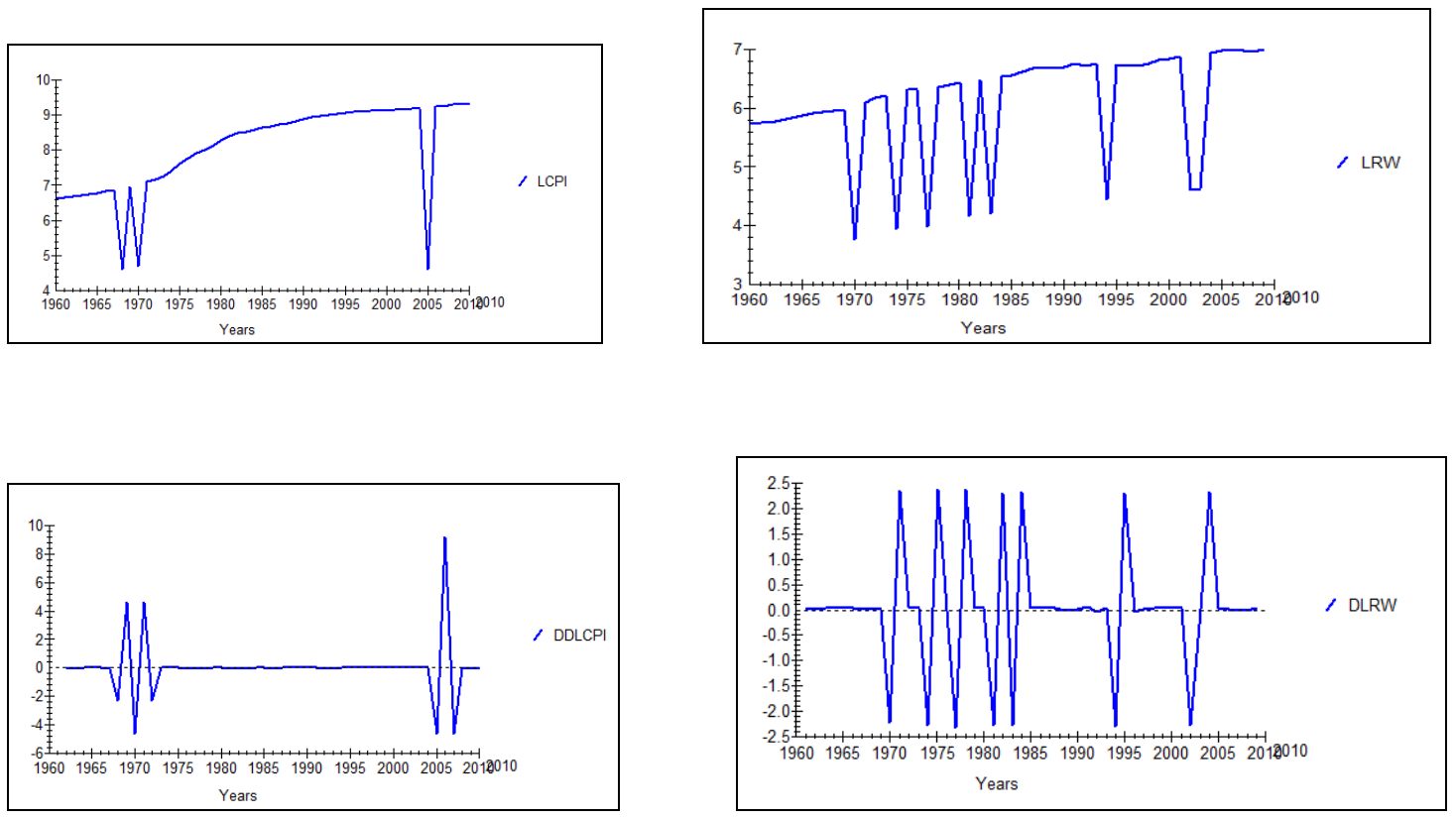


\section{Appendix 4 Test for cointegration}

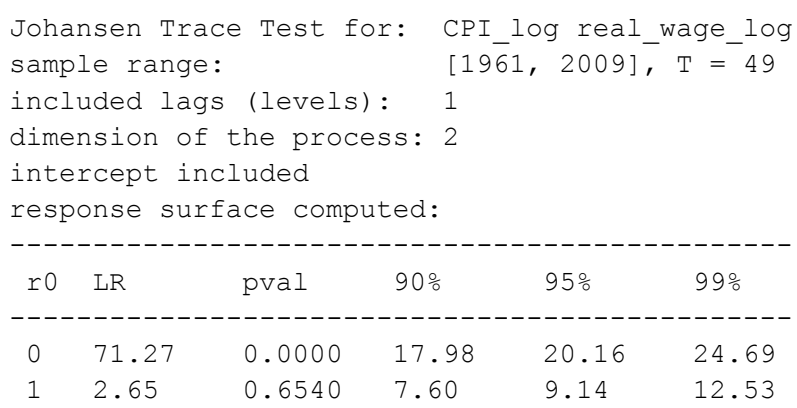

OPTIMAL ENDOGENOUS LAGS FROM INFORMATION CRITERIA

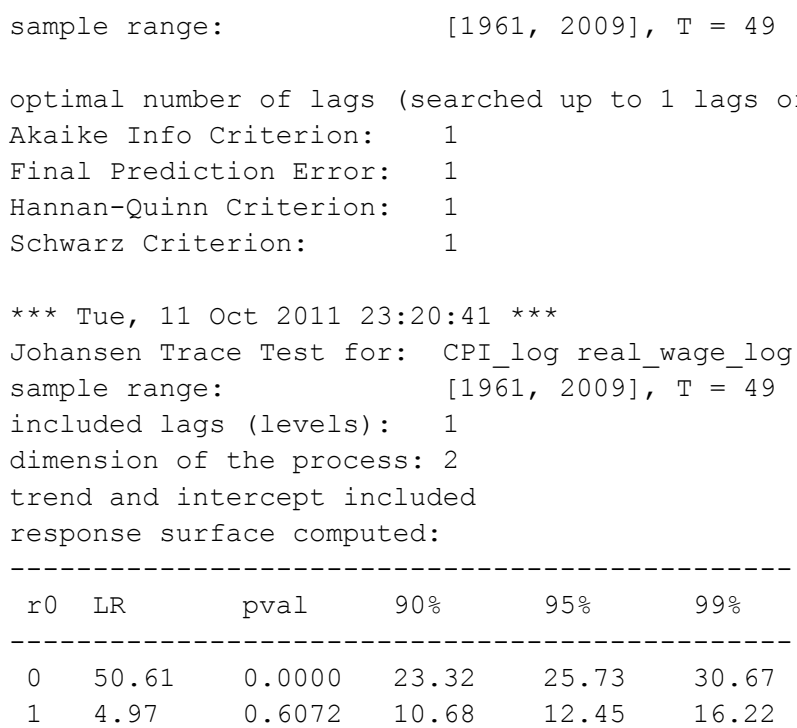

OPTIMAL ENDOGENOUS LAGS FROM INFORMATION CRITERIA

sample range:

$[1961,2009], T=49$

optimal number of lags (searched up to 1 lags of levels): Akaike Info Criterion: 1

Final Prediction Error: 1

Hannan-Quinn Criterion: 1

Schwarz Criterion: 1 
VEC REPRESENTATION

endogenous variables: exogenous variables: deterministic variables: endogenous lags (diffs): exogenous lags:

sample range:

estimation procedure:
CPI log real wage log

productivity_log

CONST TREND

0

[1961, 2009], $T=49$

one stage. Johansen approach

Deterministic term:

\begin{tabular}{|c|c|c|}
\hline & $d\left(C P I \_l \circ g\right)$ & d(real_wage_log) \\
\hline TREND ( $t$ ) & -0.010 & -0.003 \\
\hline & $(0.001)$ & $(0.001)$ \\
\hline & $\{0.000\}$ & $\{0.002\}$ \\
\hline & {$[-10.933]$} & {$[-3.068]$} \\
\hline
\end{tabular}

Loading coefficients:

\begin{tabular}{|c|c|c|}
\hline & $\mathrm{d}(\mathrm{CPI}$ I $\mathrm{Og})$ & d(real_wage_log) \\
\hline & & \\
\hline $\operatorname{ecc}(t-1)$ & -0.105 & -0.031 \\
\hline $\mid$ & $(0.008)$ & $(0.008)$ \\
\hline । & $\{0.000\}$ & $\{0.000\}$ \\
\hline & {$[-12.616]$} & {$[-3.907]$} \\
\hline
\end{tabular}

Estimated cointegration relation(s):

ec1 $(t-1)$

$\begin{array}{rrr}\text { CPI_log }(t-1) & 1.000 \\ & (0.000) \\ & \{0.000\} \\ \text { real_wage_log }(t-1) & {[0.000]} \\ & (0.504) \\ & \{0.000\} \\ \text { CONST } & {[-10.401]} \\ & 15.325 \\ & (1.746) \\ & \{0.000\} \\ & {[8.779]} \\ & \mid\end{array}$

VAR REPRESENTATION

modulus of the eigenvalues of the reverse characteristic polynomial:

$|z|=\left(\begin{array}{lll}1.0000 & 0.9478\end{array}\right)$

Legend:

$=====$

Equation 1 Equation $2 \quad \ldots$

-----------------------------------

Variable 1 | Coefficient $\quad .$.

l (Std. Dev.)

I $\{\mathrm{p}$ - Value $\}$

| [t - Value $]$

Variable 2 | 
Lagged endogenous term:

CPI_log real_wage_log

\begin{tabular}{r|cc} 
CPI_log $(t-1)$ & 0.895 & -0.031 \\
& $(0.008)$ & $(0.008)$ \\
& $\{0.000\}$ & $\{0.000\}$ \\
real_wage_log $(t-1)$ & 0.553 & 1.161 \\
& $(0.044)$ & $(0.041)$ \\
& $\{0.000\}$ & $\{0.000\}$ \\
& {$[12.616]$} & {$[28.251]$}
\end{tabular}

Deterministic term:

$=================$

CPI_log real_wage_log

\begin{tabular}{|c|c|c|}
\hline \multirow[t]{4}{*}{ TREND ( $t$ ) } & -0.010 & -0.003 \\
\hline & $(0.000)$ & $(0.000)$ \\
\hline & $\{0.000\}$ & $\{0.000\}$ \\
\hline & {$[0.000]$} & {$[0.000]$} \\
\hline \multirow[t]{4}{*}{ CONST } & -1.616 & -0.469 \\
\hline & $(0.000)$ & $(0.000)$ \\
\hline & $\{0.000\}$ & $\{0.000\}$ \\
\hline & {$[0.0000]$} & {$[0.000]$} \\
\hline
\end{tabular}


Residual analysis in VECM
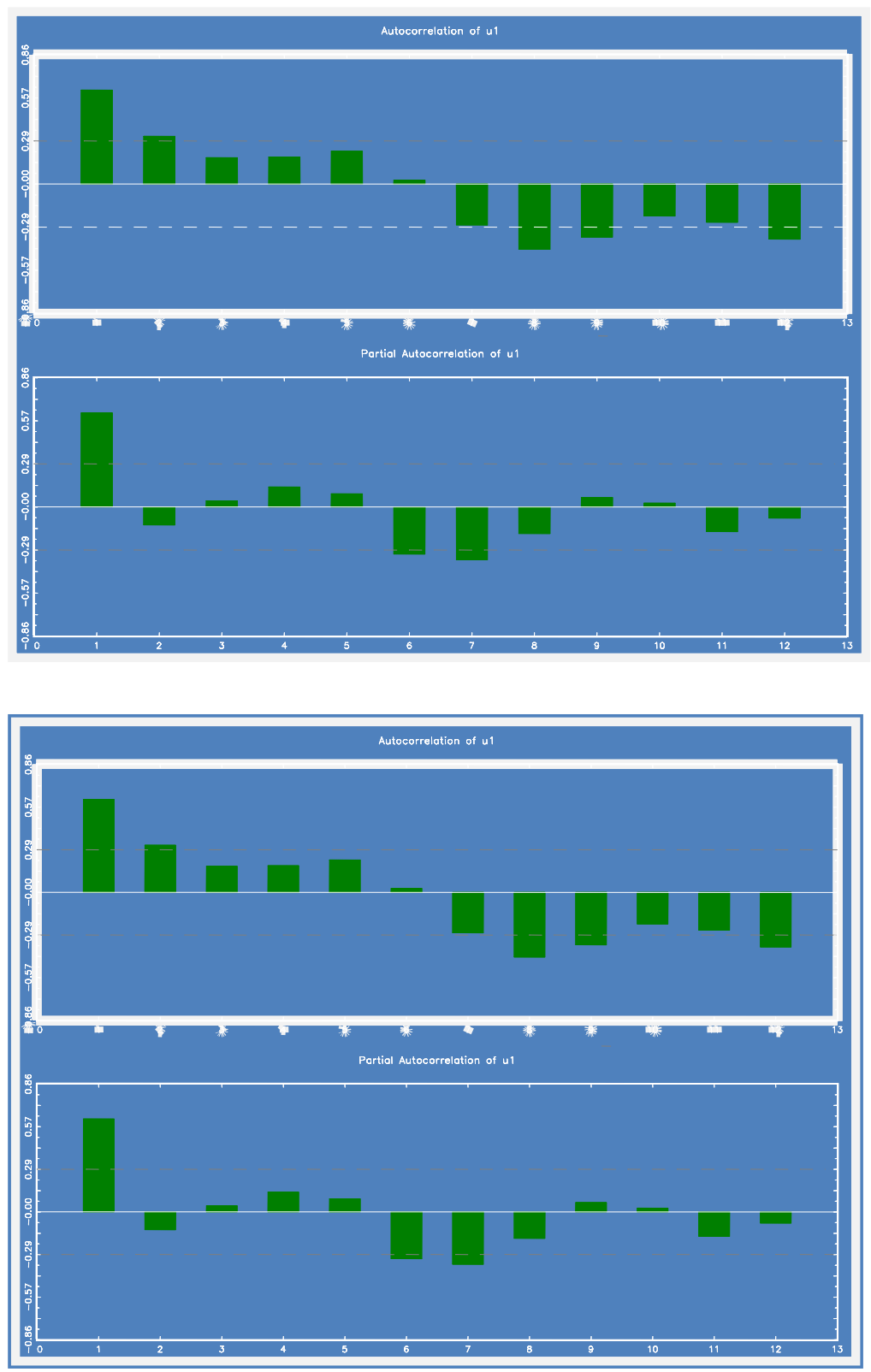
1. Gregory,D., Schweitzer, M.,(2000), Does wage cause Price inflation?, Federal Reserve Bank of Cleveland

2. Groshen,E., Schweitzer,M.(1997), The Effects of Inflation on Wage Adjustments in Firm-Level Data: Grease or Sand?, Federal Reserve Bank of New York, Federal Reserve Bank of Cleveland

3. Heo, S(2003), THE RELATIONSHIP BETWEEN EFFICIENCY WAGES AND PRICE INDEXATION IN A NOMINAL WAGE CONTRACTING MODEL,

4. Mihaljek ,D,Sweta,S, (2010)Wages, productivity and "structural" inflation in emerging market economies, BIS Papers No 49 JOURNAL OF ECONOMIC DEVELOPMENT Volume 28, Number 2,

5. Kawasaki, K., Hoeller,P., Poret,P.(1990), Modeling wages and prices for smaller OECD economies, OECD department of economics and statistics

6. Kumar,S,Webber,D,Perry, G,. (2008), Real wages, inflation and labour productivity in Australia, Department of Business Economics, Auckland University of Technology, New Zealand

7. Mihajlek, D,Sweta, S., Wages, productivity and "structural" inflation

8. Peter Flaschel, GÄoran Kauermann, Willi Semmler,(2005), Testing Wage and Price Phillips Curves for the United States, Center for Economic Policy Analysis, at the Department of Economics of the New School and the CEM Bielefeld

9. Robertson,R.,(2001), Relative Prices and Wage Inequality:Evidence from Mexico, Department of Economics Macalester College

10. Straus,J.Wohar,M.(2004), The Linkage Between Prices, Wages, and Labor Productivity:A Panel Study of Manufacturing Industries, Department of Economics, Saint Louis University, University of Nebraska at Omaha

11. Taylor, J.,(1998), STAGGERED PRICE AND WAGE SETTING IN MACROECONOMICS, Stanford University

12. Hoxha A., (2010), Causal relationship between prices and wages:VECM analysis for Germany, Department of Economics, Faculty of Economy, University of Prishtina 